\title{
EU Citizenship: Some Systemic Constitutional Implications
}

\author{
Dimitry Kochenov*
}

\section{Citizenships in Europe: Harmony and Conflict}

The EU boasts layered citizenships ${ }^{1}$ - the nationalities of the Member States are supplemented by an "additional",2 "independent"3 EU-level citizenship granted to Member State nationals and impossible without the nationalities of the Member States. ${ }^{4}$ According to the Court of Justice, it is "destined to be the fundamental status of nationals of the Member States". 5 This programme outlined by the shapers of the law is slowly being fulfilled, unsurprisingly, as

* Professor of European Constitutional Law and Citizenship, University of Groningen (The Netherlands); Associate of the European Union Programme at Princeton University (New Jersey). I am grateful to Sarah Ganty, Harry Panagopoulos, Kyrill Ryabtsev and Flips Schøyen for the help with the earlier drafts of this chapter.

1 Schönberger, C. (2005). Unionsbürger: Europas föderales Bürgerrecht in vergleichender Sicht. Tübingen: Mohr Siebeck.

2 Art. 20 TFEU.

3 Opinion of AG Poiares Maduro delivered on 30 September 2009, case C-135/o8, Janko Rottmann v. Freistaat Bayern, para. 23.

4 Schönberger, C. (2007). European Citizenship as Federal Citizenship: Some Citizenship Lessons of Comparative Federalism. European Review of Public Law 19(1); Szpunar, M., and Blas López, M.E. (2017). Some Reflections on Member States Nationality: A Prerequisite of EU Citizenship and an Obstacle to Its Enjoyment. In: Kochenov, ed., EU Citizenship and Federalism: The Role of Rights, Cambridge: Cambridge University Press. See also H.U. Jessurun d'Oliveira's chapter in this volume.

5 E.g. Court of Justice, judgment of 20 September 2001, case C-184/99, Rudy Grzelczykv. Centre public d'aide sociale d'Ottignies-Louvain-la-Neuve, para. 31; Court of Justice, judgment of 17 September 2002, case C-413/99, Baumbast and $R v$. Secretary of State for the Home Department, para. 82; Court of Justice, judgment of 8 March 2011, case C-34/o9, Gerardo Ruiz Zambrano v. Office national de l'emploi (ONEm), para. 41; Court of Justice, judgment of 2 June 2016, case C-438/14, Nabiel Peter Bogendorff von Wolffersdorffv. Standesamt der Stadt Karlsruhe and Zentraler Juristischer Dienst der Stadt Karlsruhe, para. 29; Court of Justice, judgment of 5 June 2018, case C-673/16, Relu Adrian Coman and Others v. Inspectoratul General pentru Imigrări and Ministerul Afacerilor Interne, para. 3 . 
the status has received a significant boost over recent decades, ${ }^{6}$ some disagreements in the literature about its occasional retreat notwithstanding. ${ }^{7}$ Ulli Jessurun d'Oliveira's age of the "pies in the sky", if it was ever correctly diagnosed at all, ${ }^{8}$ is now definitely over, even if the question is open as to what precisely to count as the starting point of its demise. Candidates for the starting moment of EU citizenship abound. The point of citizenship's proverbial "birth" could overlap with Ruiz Zambrano, ${ }^{9}$ Rottmann, ${ }^{10}$ Grzelczyk,, 11 Martínez

6 Kostakopoulou, D. (2005). Ideas, Norms and European Citizenship: Explaining Institutional Change. Modern Law Review 68 (2), pp. 233-267; Palombella, G. (2005). Whose Europe? After the Constitution: A Goal-Based Citizenship. International Journal of Constitutional Law 3 (2/3), pp. 357-382, 377; Kochenov, D. (2011). A Real European Citizenship; A New Jurisdiction Test; A Novel Chapter in the Development of the Union in Europe. Columbia Journal of European Law 18 (1), pp. 56-109.

7 Garner, O. (2018). The Existential Crisis of Citizenship of the European Union: The Argument for an Autonomous Status. Cambridge Yearbook of European Legal Studies 20, pp. 116146; Nic Shuibhne, N. (2017). Recasting EU Citizenship as Federal Citizenship: What Are the Implications for the Citizen When the Polity Bargain Is Privileged? In: Kochenov, ed., EU Citizenship and Federalism: The Role of Rights, cit.; Spaventa, E. (2017). Earned Citizenship - Understanding Union Citizenship through Its Scope. In: Kochenov, ed., EU Citizenship and Federalism: The Role of Rights, cit.; Yong, A. (2019). The Rise and Decline of Fundamental Rights in EU Citizenship. Oxford: Hart Publishing.

8 Jessurun d'Oliveira, H.U. (1995). Union Citizenship: Pie in the Sky? In: Rosas, Antola, eds., A Citizens' Europe. In Search of a New Order. London: Sage Publications, p. 58. See his chapter in this volume for the evolution of his views.

9 Ruiz Zambrano, cit.; D. Kochenov, A Real European Citizenship cit.; Platon, S. (2012). Le champ d'application des droits du citoyen européen après les arrêts Zambrano, McCarthy et Dereci: de la boîte de Pandore au labyrinth du Minotaure. Revue trimestrielle de droit européen 48 (1), pp. 23-52; van den Brink, M. (2012). EU Citizenship and EU Fundamental Rights: Taking EU Citizenship Rights Seriously? Legal Issues of Economic Integration 39 (2), pp. 273-289; Hailbronner, M., and Iglesias Sánchez, S. (2011). The European Court of Justice and Citizenship of the European Union: New Developments Towards a Truly Fundamental Status. Vienna Journal on International Constitutional Law 5 (4), pp. 498-537.

10 Court of Justice, judgment of 2 March 2010, case C-135/o8, Janko Rottmann v. Freistaat Bayern; Davies, G. The Entirely Conventional Supremacy of Union Citizenship and Rights. In: Shaw, ed., Has the European Court of Justice Challenged Member State Sovereignty in Nationality Law? EUI Working Papers RSCAS 2011/62; Kochenov, D. (2010). Case C-135/ o8, Janko Rottmann v. Freistaat Bayern, Judgment of the Court (Grand Chamber) of 2 March 2010. Common Market Law Review 47 (6), pp. 1831-1846; de Groot, G.-R. (2010). Overwegingen over de Janko Rottmann-beslissing van het Europese Hof van Justitie. Asielen Migrantenrecht (5/6), pp. 293-300; Jessurun d'Oliveira, H.U. (2010). Ontkoppeling van nationaliteit en Unieburgerschap? Nederlands Juristenblad 16, pp. 1028-1033; Iglesias Sánchez, S. (2010). ¿Hacia una nueva relación entre la nacionalidad estatal y la cuidadanía europea? TJUE Sentencia de 2 de marzo de 2010 (gran sala), Janko Rottmann c. Freistaat Bayern, Asunto C-135/o8. Revista de derecho comunitario europeo 37, pp. 933-95o. Grzelczyk, cit. 
Sala, ${ }^{12}$ the Treaty of Maastricht, ${ }^{13}$ Micheletti ${ }^{14}$ or could have even taken place earlier than that. ${ }^{15}$ Important rights effective throughout all EU territory accrue to this supranational citizenship, which stems directly from EU law, thus fulfilling the historic prophecy of Van Gend en Loos concerning the "constitutional heritage" of every European. ${ }^{16}$ However, this picture is nuanced by the fact that EU citizenship is sometimes, quite surprisingly, characterised as "not intended to enlarge the scope ratione materiae [of EU law]"17 - a dictum of the Court which is most likely ultra vires, ${ }^{18}$ and certainly significantly out of tune with the case law in other areas. Having been dissected and criticised by the author with Sir Richard Plender elsewhere ${ }^{19}$ this formula is most likely bad law by now.

This chapter aims to appraise the core legal significance of the status of Eurpean citizenship and to engage critically with the key mantras appended to it. I claim that EU citizenship directly questions the assumptions underlying the notions of statehood; citizenship; democracy; and equality. Moreover, this "additional" legal status could emerge as an enemy of the nationalities of the Member States, rather than their friend.

12 Court of Justice, judgment of 12 May 1998, case C-85/96, María Martínez Sala v. Freistaat Bayern. See also Opinion of AG La Pergola delivered on 1 July 1997, case C-85/96, María Martínez Sala v. Freistaat Bayern, para. 18.

13 Closa, C. (1995). Citizenship of the Union and Nationality of Member States. Common Market Law Review 32 (2), pp. 487-518. Cf. O'Leary, S. (1996), The Evolving Concept of Community Citizenship: From the Free Movement of Persons to Union Citizenship. The Hague-Boston: Kluwer Law International, 1996.

14 Court of Justice, judgment of 7 July 1992, case C-369/9o, Mario Vicente Micheletti and others v. Delegación del Gobierno en Cantabria, para. 10.

15 Maas, W. (2007). Creating European Citizens. Lanham MD: Rowman \& Littlefield; Jacobs, F.G., ed.(1976). European Law and the Individual. Amsterdam: North-Holland.

16 Court of Justice, judgment of 5 February 1963, case 26/62, NV Algemene Transport- en Expeditie Onderneming van Gend \& Loos v. Netherlands Inland Revenue Administration. Due, O. (1994). The Law-Making Role of the European Court of Justice Considered in Particular from the Perspective of Individuals and Undertakings. Nordic Journal of International Law 63 (1), pp. 123-137.

17 Court of Justice, judgment of 5 June 1997, joined cases C-64/96 and C-65/96, Land Nordrhein-Westfalen v. Kari Uecker and Vera Jacquet v. Land Nordrhein-Westfalen, para. 23 .

18 Although Paul Craig does not use it as an example in his notable account: Craig, P. (2011). The ECJ and Ultra Vires Action: A Conceptual Analysis. Common Market Law Review 48 (2), pp. 395-437.

19 Kochenov, D., and Plender, R. (2012). EU Citizenship: From an Incipient Form to an Incipient Substance? The Discovery of the Treaty Text. European Law Review 37, pp. 369-396. 
Crucially, EU citizenship is one of those rare legal statuses which, although entirely dependent on the determination of the boundary of the material scope of the law which created $i t^{20}$ - being a derivative supranational legal status produced by a Union founded on the principle of conferral. ${ }^{21}$ Even though the Union is obviously capable to affect the substance of national citizenship laws of the Member States to some extent, ${ }^{22}$ by prohibiting, for instance, non-recognition of lawfully acquired each-other's nationalities ${ }^{23}$ or through subjecting the loss of EU citizenship to EU-level scrutiny based, inter alia, on the principle of proportionality, ${ }^{24}$ what escapes the EU's non-vigilant eye is remarkable, including racist framing of citizenship ${ }^{25}$ and expatriation without any prior notice, ${ }^{26}$ leading to the treatment of law-abiding EU citizens worse than suspected terrorists. ${ }^{27}$

Most importantly - and bizarrely, should the EU's 'constitutional' claims be taken seriously - EU citizenship is not yet unquestionably endowed with fundamental rights. ${ }^{28}$ While numerous EU citizenship rights are obviously

20 See, for a very detailed account, Kochenov, D., ed.(2017).EUCitizenship and Federalism:The Role of Rights, cit.

21 For a detailed dissection of the application of the principles to the field of EU citizenship law, see: Sarmiento, D. (2019). EU Competence and the Attribution of Nationality in Member States. IMC Research Paper (Geneva) No. 2019/o2; Weingerl, P. and Tratnik, M. (2021). Relevant Links: Investment Migration as an Expression of National Autonomy in Matters of Nationality. In: Kochenov and Surak, eds., The Law of Citizenship and Money. Cambridge: Cambridge University Press.

22 Cf. Kochenov, D. (2012). Member State Nationalities and the Internal Market. In: Nic Shuibhne and Gormley, eds., From Single Market to Economic Union: Essays in Memory of John A. Usher. Oxford: Oxford University Press.

23 Micheletti, op cit.; Cf. Tratnik, M., and Weingerl, P. (2019). Investment Migration and State Autonomy: A Quest for the Relevant Link. IMC Research Paper (Geneva) No. 2019/o4.

24 Rottmann, op cit. Cf. Kochenov, D. (2010). Case C-135/o8, Janko Rottmann v. Freistaat Bayern, Judgment of the Court (Grand Chamber) of 2 March 2010, cit.; de Groot, G.-R. (2010). Overwegingen over de Janko Rottmann-beslissing van het Europese Hof van Justitie, cit.; Iglesias Sánchez, S. (2010). ¿Hacia una nueva relación entre la nacionalidad estatal y la cuidadanía europea?, cit..

25 Kaur, op cit. Cf. for the context: Lord Lester of Herne Hill, A. (2002). Thirty Years On: The East African Case Revisited. Public Law 47, pp. 52-72; Tyler, I. (2010). Designed to Fail: A Biopolitics of British Citizenship. Citizenship Studies 14(1), pp. 61-74.

26 Tjebbes, op cit. Kochenov, D. (2019). The Tjebbes Fail. European Papers 4 (1), pp. 319-336; de Groot, G.-R. (2019). Beschouwingen over Tjebbes. Asiel en Migrantenrecht, pp. 196-203.

27 Cf. Kochenov, D. (2019), The Tjebbes Fail, cit.

28 Yong, A. (2019). The Rise and Decline of Fundamental Rights of EU Citizenship. Oxford: Hart Publishing.; Sharpston, E. (2012). Citizenship and Fundamental Rights - Pandora's Box or a Natural Step Towards Maturity? In: Cardonnel, Rosas and Wahl, eds., Constitutionalising the EU Judicial System: Essays in Honour of Pernilla Lindh. Oxford: Hart Publishing. Cf. 
there - and this volume scrutinises an array of those in detail too, from free movement and family reunification ${ }^{29}$ to social assistance, ${ }^{30}$ citizens' initiative $^{31}$ and fundamental rights in times of economic crisis, ${ }^{32}$ to freedom to move investments around the Union ${ }^{33}$ and voting rights ${ }^{34}$ - the dependence of any EU citizenship rights claims on the division of competences between the EU and the Member States unquestionably demonstrates the far-reaching limits of EU citizenship. ${ }^{35}$ This is because the division of competences between the EU and the Member States generally follows what one can term as a cross-border or internal market logic. ${ }^{36}$ Consequently, the actual usefulness of supranational citizenship in taming the negative externalities of the internal market, as well as in establishing a firm ethical and moral grounding and justification for EU citizenship outside the frame of the internal market has been, although theoretically possible, ${ }^{37}$ truly feeble if not non-existent in practice. ${ }^{38}$ The result has been the weakening of the EU's justice claims, ${ }^{39}$ and the punishment and undermining of the life-chances of those citizens who fail to qualify as "good enough" when scrutinised through the internal market lens. ${ }^{40}$ One of the core

Iglesias Sánchez, S. (2014). Fundamental Rights and Citizenship of the Union at a Crossroads: A Promising Alliance or a Dangerous Liaison? European Law Journal 20 (4), pp. 464-481; Kochenov, D., and Plender, R. (2014). EU Citizenship: From an Incipient Form to an Incipient Substance? cit.; Caro de Sousa, P. (2014). Quest for the Holy Grail - Is a Unified Approach to the Market Freedoms and European Citizenship Justified? European Law Journal 20 (4), pp. 499-519.

29 See the chapters by H. Kroeze and N. Cambien in this volume.

30 See the chapters by E. Muir and by M. Jesse and D. Carter in this volume.

31 See the chapter by N. Athanasiadou in this volume.

32 See the chapter by K. Kalaitzaki in this volume.

33 See the chapter by S. Kudryashova in this volume.

34 See the chapter by S. Platon in this volume.

35 van den Brink, M. (2019). EU Citizenship and (Fundamental) Rights: Empirical, Normative, and Conceptual Problems. European Law Journal 25 (1), pp. 21-36.

36 See, most importantly, Tryfonidou, A. (2009). Reverse Discrimination in EC Law. Alphen aan den Rijn: Kluwer Law International.

37 E.g. Kochenov, D. (2013), The Right to Have What Rights? EU Citizenship in Need of Clarification. European Law Journal 19 (4), pp. 502-516.

38 O'Brien, C. (2016). Civis Capitalist Sum: Class as the New Guiding Principle of EU Free Movement Rights. Common Market Law Review 53 (4), pp. 937-978; Caro de Sousa, P. (2014). Quest for the Holy Grail, cit.; Peebles, G. (1997). "A Very Eden of the Innate Rights of Man"? A Marxist Look at the European Union Treaties and Case Law. Law and Social Inquiry 22 (3), pp. 581-618.

39 de Búrca, G. (2015). Conclusion. In: Kochenov, de Búrca, and Williams, eds., Europe's Justice Deficit? Oxford-Portland: Hart Publishing.

40 That a citizenship would punish those who do not qualify as "good citizens" in the eyes of the authority in charge is one of the core functions of the legal status. On this count the $\mathrm{EU}$ is not at all atypical, compared with any other public authority in the world, which 
features of the EU as it stands consists, accordingly, in ignoring the pain of such unworthy citizens and failing to help those in need, explaining away their plight, as Charlotte O'Brien among others has splendidly demonstrated. ${ }^{41}$ As far as EU law is concerned, those who are not "good enough" for its scope do not exist, falling between the cracks in the dogmas of the internal market rationality, brought down by EU law.

It is while burnishing the label on this citizenship which fosters its internal market logic, ignoring the vulnerable instead of defending citizenship bearers from market externalities, that the oxymoronic "market citizenship" was born. ${ }^{42}$ With respect to those proclaiming it - and they are no doubt correct in their meticulous engagement with the case law ${ }^{43}$ - "market citizenship" is without doubt a misnomer: it simply cannot be taken seriously unless deployed, as the majority of the literature has done, purely descriptively. The reason for this is that to do more requires an inevitable reversal of all the key principles informing the understanding of citizenship and the reasons for the articulation of the term in the first place, which occurs when the full enjoyment of this citizenship's rights and status is made the prize for one's employability and history of travel around the Union, instead emerging from any idea of equality before the law and protecting the vulnerable. ${ }^{44}$

selects "citizens" among the available bodies, whatever criteria are employed: Kochenov, D. (2019). Citizenship. Cambridge MA: MIT Press.

41 O'Brien, C. (2017). Unity in Adversity: EU Citizenship, Social Justice and the Cautionary Tale of the UK. Oxford-Portland: Hart Publishing; Ganty, S. (2021). L'intégration des citoyens européens et des ressortissants de pays tiers en droit de l'Union européenne. Critique d'une intégration choisie. Brussels. Larcier.

42 Nic Shuibhne, N. (2010). The Resilience of EU Market Citizenship. Common Market Law Review 47 (4), pp. 1597-1628; O'Brien, C. (2016). Civis Capitalist Sum: Class as the New Guiding Principle of EU Free Movement Rights, cit.; Kochenov, D. (2019). The Oxymoron of "Market Citizenship" and the Future of the Union. In: Amtenbrink et al., eds., The Internal Market and the Future of European Integration. Cambridge: Cambridge University Press, p. 217.

43 Nic Shuibhne, N. (2015). Limits Rising, Duties Ascending: The Changing Legal Shape of Union Citizenship. Common Market Law Review $5^{2}$ (4), pp. 889-937; Nic Shuibhne, N. (2017). Recasting EU Citizenship as Federal Citizenship: What Are the Implications for the Citizen When the Polity Bargain Is Privileged? In: Kochenov, ed., EU Citizenship and Federalism: The Role of Rights, cit.; van den Brink, M. (2019). EU Citizenship and (Fundamental) Rights, cit.

44 See, for a very detailed treatment, Kochenov, D. (2017). On Tiles and Pillars: EU Citizenship as the Federal Denominator. In: Kochenov, ed., EU Citizenship and Federalism: The Role of Rights, cit., p. 3 (and the literature cited therein). 
All the talk of democracy and rights ${ }^{45}$ within the unchangeable market citizenship paradigm ${ }^{46}$ could thus be nothing but a renewed entrenchment and glorification of the "wholly internal situation" and "reverse discrimination" thinking. It comes accompanied by the presumption that those who opt to remain outwith the scope of EU law ${ }^{47}$ - by staying at home for instance ${ }^{48}$ deserve zero protection and respect within the legal context of the Union. This is an old and deeply troubling story ably characterised by Joseph Weiler as the loss by the Union of a mantle of ideals - and not much has changed in all the years since this characterisation appeared in print. ${ }^{49}$ By connecting human worth and dignity, any claim to rights, to employability and the mantras of a citizen's usefulness in the context of the Internal Market, "market citizenship" is the epitome of the ideological space where a human being is openly - not tacitly - commodified, and those evading commodification or perceived as not useful enough are not deemed worthy of the quasi-citizenship at stake. ${ }^{50}$ They are not "market citizens" and any other citizenship is apparently not on offer.

The result of this is troubling. When made dependent on the division of competences in the scope of the rights it protects, EU citizenship is turned into a neo-mediæval "citizenship of personal circumstances": ${ }^{51}$ a judge first needs to see your full CV with all your jobs, travel history, ${ }^{52}$ the nationality of your

45 Lenaerts, K., and Gutiérrez-Fons J.A. (2017). Epilogue on EU Citizenship: Hopes and Fears. In: Kochenov, ed., EU Citizenship and Federalism: The Role of Rights, cit.; chapter by S. Platon in this volume.

46 Davies, G. (2015). Social Legitimacy and Purposive Power: The End, the Means and the Consent of the People. In: Kochenov, de Búrca, and Williams, eds., Europe's Justice Deficit?, cit.; Somek, A. (2014). Europe: Political, Not Cosmopolitan. European Law Journal 20 (2), pp. $142-163$.

47 E.g. H. Kroeze in this volume.

48 Iglesias Sánchez, S. (2017). A Citizenship Right to Stay? The Right Not to Move in a Union Based on Free Movement. In: Kochenov, ed., EU Citizenship and Federalism: The Role of Rights, cit.; Davies, G. (2017). A Right to Stay at Home: A Basis for Expanding European Family Rights. In: Kochenov, ed., EU Citizenship and Federalism: The Role of Rights, cit., p. 468.

49 Weiler, J.H.H. (1998). Bread and Circus: The State of the European Union. Columbia Journal of European Law 4 (11), pp. 223-248, p. 231.

50 Peebles, G. (1997). "A Very Eden of the Innate Rights of Man"? cit.; Caro de Sousa, P. (2014). Quest for the Holy Grail, cit.; O'Brien, C. (2016). Civis Capitalist Sum: Class as the New Guiding Principle of EU Free Movement Rights, cit.; Kochenov, D. (2017). On Tiles and Pillars: EU Citizenship as the Federal Denominator, cit., pp. 3-82.

$5^{1}$ Kochenov, D. (2018). The Citizenship of Personal Circumstances in Europe. In: Thym, ed., Questioning EU Citizenship. Oxford-Portland: Hart Publishing, pp. 37-56.

$5^{2}$ Court of Justice, judgment of 5 May 2011, case C-434/og, Shirley McCarthy v. Secretary of State for the Home Department; Nic Shuibhne, N. (2012). (Some of) the Kids Are All Right: Comment on McCarthy and Dereci. Common Market Law Review 49 (1), pp. 349-38o. 
current and former spouses, ${ }^{53}$ partners and children, ${ }^{54}$ and bank accounts, ${ }^{55}$ to see whether you - a citizen - "deserve" any EU citizenship rights. ${ }^{56}$ This story would not be complete without mentioning that, unlike in the earlier case law, dual nationality could be interpreted against you, as David de Groot's ground-breaking research has shown. ${ }^{57}$ Neither disability nor pregnancy will help characterise you as a "good" EU citizen either. ${ }^{58}$ A truly minor crime will disqualify you from supranational rights, dignity and respect. ${ }^{59}$ Not even being deemed a worker is enough anymore:60 EU law will eagerly side with the Member States oppressing their ethnic and linguistic, and presumably other minorities, as long as frowning upon these groups is part of their "constitutional identity", thus capable of creating a de facto wholly internal situation,

53 Court of Justice, judgment of 12 July 2005, case C-403/o3, Egon Schempp v. Finanzamt München V;; Spaventa, E. (2008). Seeing the Wood Despite the Trees? On the Scope of Union Citizenship and Its Constitutional Effects. Common Market Law Review 45 (1), pp.13-45, p. 21, note 34 .

54 Coman, cit.; Court of Justice, judgment of 14 November 2017, case C-165/16, Toufik Lounes v. Secretary of the Home Department. Very much depends on whether one of the spouses is an EU citizen and whether this citizenship counts: also Titshaw, S. (2016). Same-Sex Spouses Lost in Translation? How to Interpret 'Spouse' in the EU Family Migration Directives. Boston University International Law Journal 34, pp. 47-115, p. 58.

55 Court of Justice, judgment of 10 October 2013, case C-86/12, Adzo Domenyo Alokpa and Others v. Ministre du Travail, de l'Emploi et de l'Immigration; Court of Justice, judgment of 19 October 2004, case C-200/o2, Kunquian Catherine Zhu and Man Lavette Chen v. Secretary of State for the Home Department. Cf. Spaventa, E. (2017). Earned Citizenship Understanding Union Citizenship through Its Scope. In: Kochenov, ed., EU Citizenship and Federalism: The Role of Rights, cit.; O'Brien, C. (2016). Civis Capitalist Sum: Class as the New Guiding Principle of EU Free Movement Rights, cit.

56 S. Ganty. L'intégration des citoyens européens et des ressortissants de pays tiers en droit de l'Union européenne. cit.

57 See the chapter by D.A.J.G. de Groot in this voume.

58 O'Brien, C. (2017). Union Citizenship and Disability: Restricted Access to Equality Rights and the Attitudinal Model of Disability. In: Kochenov, ed., EU Citizenship and Federalism: The Role of Rights, cit.; O'Brien, C. (2016). Civis Capitalist Sum: Class as the New Guiding Principle of EU Free Movement Rights, cit.

59 Belavusau, U., and Kochenov, D. (2016). Kirchberg Dispensing the Punishment: Inflicting 'Civil Death' on Prisoners in Onuekwere (C-378/12) and M.G. (C-40o/12). European Law Review 40, pp. 557-577; O’Brien, C. (2008). Real Links, Abstract Rights and False Alarms: The Relationship between the ECJ's "Real Link" Case Law and National Solidarity. European Law Review 5, pp. 643-665.

6o This development was predicted by Síofra O'Leary long ago: O'Leary, S. (2008). Developing an Ever Closer Union between the Peoples of Europe?: A Reappraisal of the Case-Law of the Court of Justice on the Free Movement of Persons and EU Citizenship. Edinburgh Mitchell Working Papers 6, pp.14-24. See, for a majestic treatment, Tryfonidou, A. (2016). Impact of Union Citizenship on the EU's Market Freedoms. Oxford-London: Hart Publishing. 
depriving "market citizens" otherwise not unworthy per se of rights under EU law. ${ }^{61}$ The result is a self-proclaimed constitutional system without a free and self-determining constitutional subject endowed with rights. ${ }^{62}$ It is a neomediæval construct where liberty and entitlements are strictly apportioned based on esoteric considerations rooted in personal histories, wealth, potential and actual employability, and travel and the willingness to do so: a triumph of contingent and morally vacant acts necessary to be performed to enter the Union's field of vision and thereby become endowed with personality in its law, which is the law which purports to have claimed you as its citizen, on top of your own national legal order. ${ }^{63}$

The main outcome of such an approach to the individual is as atypical as it is troubling: before a person's CV and bank accounts have been investigated, the most fundamental, essential legal principles of Western constitutionalism will not apply. This especially concerns equality before the law, which does not kick in if you are too poor, like Miss Dano; ${ }^{64}$ too pregnant, like Jessy Saint Prix; ${ }^{65}$ or too Polish for the Lithuanian state, like Małgorzata Runiewicz. We are thus confronted by the lack of equality before the law as the main starting principle for dealing with EU citizens ${ }^{66}$ in a context where the EU produces and constantly re-enacts a neo-mediæval presumption of difference the goodness of which is presumed and does not per se require

61 Court of Justice, judgment of 12 May 2011, case C-391/og, Malgožata Runevič-Vardyn and Łukasz Pawet Wardyn v. Vilniaus miesto savivaldybès administracija and Others. The case is analysed in this vein in Kochenov, D. (2018). When Equality Directives are Not Enough: Taking an Issue with the Missing Minority Rights Policy in the EU. In: Belavusau, and Henrard, eds., EU Anti-Discrimination Law beyond Gender. Oxford-London: Hart Publishing. Cf. Dagylitè, E. et al. (2015). The Importance of Being Earnest: Spelling of Names, EU Citizenship and Fundamental Rights. Croatian Yearbook of European Law and Policy 11, pp. 1-45.

62 Cf. Azoulai, L., Barbou des Places, S., and Pataut, E., eds. (2016). Constructing the Person in EU Law: Rights, Roles, Identities. Oxford-Portland: Hart Publishing.

63 Kochenov, D. (2017). On Tiles and Pillars: EU Citizenship as the Federal Denominator, cit., pp. $3-82$.

64 See the chapter by M. Jesse and D. Carter in this volume.

65 Court of Justice, judgment of 19 June 2014, case C-507/12, Jessy Saint Prix v. Secretary of State for Work and Pensions; Ganty, S. 'Citoyenneté européenne et genre: approche critique de la directive 2004/38/CE'. In: Bernard and Harmel (eds.). Code commenté - Droits des femmes. Brussels: Larcier, 2020, pp. 303-307; Currie, S. (2016). Pregnancy-Related Employment Breaks, the Gender Dynamics of Free Movement Law and Curtailed Citizenship: Jessy Saint Prix. Common Market Law Review 53 (2), pp. 543-562.

66 For a broader analysis of the legality in the context of EU law, see, Somek, A. (2017). Is Legality a Principle of EU Law? In: Vogenauer and Weatherill, eds., General Principles of Law: European and Comparative Perspectives. Oxford: Hart Publishing. 
justification. ${ }^{67}$ Why this is the case has been explained to the citizens a thousand times: Niamh Nic Shuibhne might indeed be right that this is the Court willing "to accept the limitations coded into the current federal bargain". 68 Yet it is not the protection of a perfect Constitution from human rights concerns - which the Court famously did, inter alia, in Opinion $2 / 13^{69}$ - but taking such concerns seriously, which ensures that legal systems are both respected and effective. Honouring the bargain, when viewed in this light, could obviously be a big problem. ${ }^{70}$

\section{b EU Citizenship: Two Lessons}

Armed with respect for the federal bargain which requires blind faith in and strict adherence to a context-sensitive neo-mediævalism, EU citizenship sends two signals. Firstly, it significantly empowers the willing Member State nationals, "good enough" in the eyes of the supranational authorities, to fall within the scope of EU law. Volumes have been written about the freedom of movement of persons and the right is significant. The very horizon of opportunities of all Member State nationals is broadened by the intercitizenship logic of the supranational status, working as a package of dozens of national legal statuses fused into one. ${ }^{71}$ Secondly, being silent on the scope of the law, EU citizenship is constantly presented to us as relatively weak, all the numerous successes reported notwithstanding. Crucially, it is respectful even when the issues to hand unquestionably fall within the scope of EU law: if a Member States wants to ignore EU law to grant fewer rights to women - it can. ${ }^{72}$ If a Member State

67 Kochenov, D. (2016). Neo-Mediæval Permutations of Personhood in the European Union. In: Azoulai, Barbou des Places, and Pataut, eds., Constructing the Person in EU Law: Rights, Roles, Identities, cit., pp. 133-158.

68 Nic Shuibhne, N. (2017). Recasting EU Citizenship as Federal Citizenship: What Are the Implications for the Citizen When the Polity Bargain Is Privileged?, cit., p. 176.

69 Opinion 2/13 (ECHR Accession II) (2014) ECLI:EU:C:2014:2454, para. 170. Eeckhout, P. (2015). Opinion 2/13 on EU Accession to the ECHR and Judicial Dialogue - Autonomy or Autarky? Fordham International Law Journal 38 (4), pp. 955-992; Kochenov, D. (2015). EU Law without the Rule of Law: Is the Veneration of Autonomy Worth It? Yearbook of European Law 34, pp. 74-96, 94.

70 Balkin, J. (1997). Agreements with Hell and Other Objects of Our Faith. Fordham Law Review 65 (4), pp. 1703-1738.

71 Kochenov, D. (2019). Interlegality - Citizenship - Intercitizenship. In: Klabbers, and Palombella, eds., The Challenge of Interlegality. Cambridge: Cambridge University Press, p. 133; Golynker, O. (2009). European Union as a Single Working-Living Space. In: Halpin, and Roeben, eds., Theorising the Global Legal Order. Oxford: Hart Publishing, p. 151.

72 O'Brien, C. (2017). The ECJ Sacrifices EU Citizenship in Vain: Commission v. United Kingdom. Common Market Law Review 54 (1), pp. 209-243. 
wishes to continue abusing its own ethnic minorities by denying them a right to a name - it can.${ }^{73}$ Both the rights of individuals and the sovereignty of the Member States thus stand protected - to a point. ${ }^{74}$ The flexibility of this arrangement seems to be key, however, which emerges as fundamental to the proverbial 'federal bargain'. Moreover, if a Member State you are associated with leaves the EU, your supranational "new" citizenship is thereby extinguished: it is not that personal after all. ${ }^{75}$

\section{I EU Citizenship: Questioning the Established Narrative}

Although the literature on EU citizenship has been booming in recent years, the absolute majority of analyses have been confined to reactions to the evergrowing and byzantine case law and trying to make sense of the Court's hints in various directions. ${ }^{76}$ This is no doubt the core of legal research and some of the contributions developing scholarship in this direction have been spectacularly illuminating. ${ }^{77}$ The majority of the contributions to this book fit equally well within this established tradition. But what if we tease the "true" lawyers a little and entertain scrutiny of the very context of EU law, using its citizenship as a pretext, in the vein of Pedro Caro de Sousa, Agustín José Menéndez, Charlotte O'Brien and Alexander Somek?78 Questioning the established story

73 Runevič-Vardyn and Wardyn, cit.; Kochenov, D. (2018). When Equality Directives are Not Enough, cit.

74 Lenaerts, K. (2012). 'Civis Europaeus Sum': From the Cross-Border Link to the Status of Citizen of the Union. In: Cardonnel, Rosas and Wahl, eds., Constitutionalising the EU Judicial System, cit.; Nic Shuibhne, N. (2017). Recasting EU Citizenship as Federal Citizenship, cit.; M. Jesse and D. Carter in this volume.

75 van den Brink, M., and Kochenov, D. (2019). Against "Associate EU Citizenship". Journal of Common Market Studies 57(6), pp. 1366-1382. But see Kostakopoulou, D. (2018). Scala Civium: Citizenship Templates Post-Brexit and the European Union's Duty to Protect EU Citizens. Journal of Common Market Studies 56 (4), pp. 854-869.

76 See, e.g. a great example of the opposing interpretations of the same case law by two of the most eminent scholars of EU citizenship: Nic Shuibhne, N. (2017). Recasting EU Citizenship as Federal Citizenship: What Are the Implications for the Citizen When the Polity Bargain Is Privileged?, cit., and Spaventa, E. (2017). Earned Citizenship Understanding Union Citizenship through Its Scope, cit.

77 E.g. Wollenschläger, F. (2010). A New Fundamental Freedom beyond Market Integration: Union Citizenship and Its Dynamics for Shifting the Economic Paradigm of European Integration. European Law Journal 17 (1), pp. 1-34; Nic Shuibhne, N. (2015). Limits Rising, Duties Ascending, cit.

78 E.g. O’Brien, C. (2017). Unity in Adversity, cit.; Menéndez, A.J. (2015). Whose Justice? Which Europe? In: Kochenov, de Búrca, and Williams, eds., Europe's Justice Deficit?, cit.; Caro de Sousa, P. (2014). Quest for the Holy Grail - Is a Unified Approach to the Market 
can be a useful way to see the well-known case law, as well as all the twists and turns of the European citizenship story, in quite a different light.

It can be argued that EU citizenship works against the established understandings of (a) statehood, (b) citizenship, (c) democracy and (d) equality, situating these in the context of cosmopolitan constitutionalism. ${ }^{79}$ The current dynamics illustrate the well-noted Joppkean global weakening of citizenship ${ }^{80}$ and the rise of a new way of organising political communities. ${ }^{81}$ European citizenship exemplifies key future global trends in citizenship and the development of constitutionalism, even if as already mentioned, with a necessary, surprising neo-mediæval twist. ${ }^{82}$

\section{a Empowering the Citizen - Humiliating the State}

EU citizenship rights are of great importance, enlarging citizens' horizons of opportunities by a factor of twenty-seven: work, residence, family reunification and non-discrimination on the basis of nationality where EU law is applicable - all have become claims to be turned against the government of any participating state, whether an EU member or not. Moreover, the direct effect of EU law, including its citizenship rights provisions, ensures that national law cannot prevail in the face of EU citizens' supranational entitlements. ${ }^{83}$ States stand "humiliated", ${ }^{84}$ obviously enjoying no power - legally at least - to close their territories and their nations to others, however friendly these are proclaimed to be. This touches the core of statehood, if not nationhood: no Member State can decide (some exceptions notwithstanding) ${ }^{85}$ who among

Freedoms and European Citizenship Justified?, cit.; Somek, A. (2012). On Cosmopolitan Self-Determination. Global Constitutionalism 1, pp. 405-428.

79 Somek, A. (2014). The Cosmopolitan Constitution, Oxford: Oxford University Press.

80 Joppke, C. (2010). The Inevitable Lightening of Citizenship. European Journal of Sociology $5^{1}(1)$, pp. 9-32.

81 Somek, A. (2014). Europe: Political, Not Cosmopolitan, cit.

82 Kochenov, D. (2016). Neo-Mediæval Permutations of Personhood in the European Union., cit. pp. $133-158$.

83 Arena, A. (2018). The Twin Doctrines of Primacy and Pre-Emption. In: Schütze, and Tridimas, eds., Oxford Principles of European Union Law: Vol. 1: The European Union Legal Order. Oxford: Oxford University Press.

84 Davies, G. (2010). The Humiliation of the State as a Constitutional Tactic. In: Amtenbrink, and Van den Berg, eds., The Constitutional Integrity of the European Union. Hague: T.M.c. Asser Press, p. 147.

85 Kostakopoulou, D. (2014). When EU Citizens Become Foreigners. European Law Journal 20 (4), pp. 447-463; Meduna, M. (2017). "Scelestus Europeus Sum": What Protection Against Expulsion Does EU Citizenship Offer to European Offenders? In Kochenov, ed., EU Citizenship and Federalism: The Role of Rights, cit. 
the EU's citizens may enter its territory, reside and work there. Going further, a similar regime applies to a huge number of foreigners too, be they EEA nationals, third country national family members of EU citizens or other privileged categories. ${ }^{86}$ Furthermore, States have lost the ability to favour "their own" - the first key feature of any citizenship, distinguishing between "us" and "them" - in a growing array of situations: the core outcome of the prohibition of discrimination on the basis of nationality in within the scope of application of EU law. ${ }^{87}$ EU citizens are now virtually always "us", striking at the heart of national citizenships. Being unable to empower "their own" affects the nature of European States. Rather than picking citizens through the framing of migration and naturalisation legislation, in the EU the States are picked by citizens directly empowered by EU law. The essential legal characteristics of European States and their nationalities are thereby seriously altered. The new reality has not yet been fully internalised by the legal-political systems of the Member States.

\section{b Promoting Democracy - Undermining Democratic Outcomes}

The implications for the nature of democracy are equally significant. In terms of procedure, EU citizens participate in EU-level and municipal-level elections in their state of residence, ${ }^{88}$ as well as being able to register citizens' initiatives, provided what these propose is within the scope of EU law. ${ }^{89}$ Even without covering national elections, the EU and its citizenship is a vehicle of democratic inclusion. Simultaneously, however, EU citizenship can shield its bearers from the application of legitimate democratic outcomes to them, once a connection with EU law is found. Having its final say, the Court of Justice then tests the reasonableness and proportionality of any national measure. This

86 Kochenov, D., and van den Brink, M. (2015). Pretending There Is No Union: Non-Derivative Quasi-Citizenship Rights of Third-Country Nationals in the EU. In: Thym, and ZoetewijTurhan, eds., Rights of Third-Country Nationals under EU Association Agreements: Degrees of Free Movement and Citizenship. Leiden-Boston: Brill/Nijhoff, p. 66.

87 Davies, G. (2003). Nationality Discrimination in the European Internal Market. The Hague: Kluwer Law International; Lenaerts, K. (2006). Union Citizenship and the Principle of Non-Discrimination on the Grounds of Nationality. In: Fenger, Vesterdorf, and HagelSørensen, eds., Festskrift til Claus Gulmann: Liber Amicorum. Copenhagen: Forlaget Thomson.

88 Cf. Fabbrini, F. (2017). The Political Side of EU Citizenship in the Context of EU Federalism. In Kochenov, ed., EU Citizenship and Federalism: The Role of Rights, cit.; S. Platon's chapter in this volume.

89 Iannì, A. (2019). The European Citizens' Initiative in the Light of the European Debt Crisis: A Gateway Between International Law and the EU Legal System. European Papers 3 (3), pp. $1159-1178$. 
potentially covers any national rule objected to by an EU citizen, including rules on nationality itself. ${ }^{90}$ Democracy's function is thus changed significantly, placing absolute emphasis on contestation. ${ }^{91}$ This produces new users of democracy: cosmopolitans fighting "unreasonable" regulation. ${ }^{92}$ While the trend is not new, ${ }^{93}$ the EU context reinforces it. Having used EU law to choose a State, EU citizens both participate in democratic decision-making and enjoy protection from its legitimate outcomes. This is valid at all levels of the law, including legislation, constitutional-level rules and the duties of State-level citizenship. That said, citizens cannot do much supranationally, given that the design of the Union prevents the essential principles of the internal market from being subjected to democratic contestation, or any other form for that matter. ${ }^{94} \mathrm{In}$ a curious ideological twist, the internal market as it stands is presented to the Europeans as rational, technocratic and apolitical, foreclosing any democratic dialogue about Europe's future development. ${ }^{95}$

\section{c Promoting Non-Discrimination-Undermining Equality}

Akin to sorting "us" from "them", equality among the holders of the status is said to be a core feature of citizenship. Its practical realisation depends on how clearly the scopes of EU and national law are delineated: both promise equality. Since, as we have seen, EU citizenship cannot bring citizens automatically within the material scope of EU law, additional factors are determinant. The law is malleable: the nationality of your former wife, ${ }^{96}$ being born across a border ${ }^{97}$

90 Rottmann, cit.; Kochenov, D. (2010). Case C-135/o8, Janko Rottmann v. Freistaat Bayern, cit.

91 Kumm, M. (2010). The Idea of Socratic Contestation and the Right to Justification: The Point of Rights-Based Proportionality Review. Law \& Ethics of Human Rights 4 (2), pp. $142-175$.

92 Somek, A. (2014). Europe: Political, Not Cosmopolitan, cit.; Somek, A. (2013). The Individualisation of Liberty: Europe's Move from Emancipation to Empowerment. Transnational Legal Theory 4 (2), pp. 258-282; Somek, A. (2012). On Cosmopolitan Self-Determination, cit.; Davies, G. (2010). Humiliation of the State as a Constitutional Tactic, cit.

93 Badiou, A. (2003). Léthique: Essai sur la conscience du mal. France: Nous.

94 E.g. Davies, G. (2015). Social Legitimacy and Purposive Power: The End, the Means and the Consent of the People. In: Kochenov, de Búrca, and Williams, eds., Europe's Justice Deficit?, cit.

95 Wilkinson, M.A. (2015). Politicising Europe's Justice Deficit: Some Preliminaries. In: Kochenov, de Búrca, and Williams, eds., Europe's Justice Deficit?, cit.; Menéndez, A.J. (2015). Whose Justice? Which Europe? In: Kochenov, de Búrca, and Williams, eds., Europe's Justice Deficit?, cit.

96 Schempp, cit.

97 Chen, cit. 
or the vague likelihood of changing States in the future ${ }^{98}$ can suffice to bring EU-level equality into play, covering a flexible group of EU citizens; though not all. While EU and national citizenships extend equally to the same people, the application of EU equality - not dependent only on status - is an either/or question which disables national equality claims, as the question is not answered by analysing the objective situation of the person concerned. The Court's attempts to frame EU law's scope through the severity of the actual or potential violation of the essence of EU-level rights ${ }^{99}$ met strong resistance, ruining clarity. When France promises equality to all Frenchmen it cannot possibly deliver, since two French neighbours living largely similar lives can be subject to two different legal systems for reasons bearing no relation to their lives or legal status. The promises of national and EU-level equality are fictitious: indeed, it is the differentiation in the face of the law, rather than equality before the law, which emerges as the main supranational - and thus national-level - legal principle, as far as EU citizenship is concerned.

\section{d Implications for the Rule of Law: the Sole Possibility of One Type of Constitutionalism}

As a result of the blurred and contested essence of EU citizenship, the nature of the state, democracy and national citizenship in the EU are profoundly transformed. By its very existence, the EU and its citizenship promote one particular type of constitutionalism ${ }^{100}$ to which the Member States are bound to adhere, which implies an emphasis on proportionality and justification, ${ }^{101}$ and a toning down of representative democracy and equality claims. Due to the penetrating nature of EU law, the relationship between the levels of the law in this model is far more complex than in the majority of "straightforward" federations: ${ }^{102}$ the EU is much more malleable and haphazard. ${ }^{103}$ Two key features of national citizenship do not hold true here: in a Union where EU law enjoys supremacy and direct effect and the scope of this law is necessarily blurred, citizenship firstly does not bring about equal treatment. Secondly, national

\footnotetext{
98 Court of Justice, judgment of 2 October 2003, case C-148/o2, Carlos Garcia Avello v. Belgian State.

99 Ruiz Zambrano, cit.

100 Perju, V. (2012). Proportionality and Freedom - An Essay on Method in Constitutional Law. Global Constitutionalism 1 (2), pp. 334-367.

101 Neyer, J. (2012). Justification of Europe: A Political Theory of Supranational Integration. Oxford: Oxford University Press.

102 Beaud, O. (2007). Théorie de la fédération. Paris: PUF.

103 Schütze, R. (2009). From Dual to Cooperative Federalism: The Changing Structure of European Law. Oxford: Oxford University Press.
} 
citizenship does not provide better treatment than other EU citizens within the scope of application of EU law. EU law thus brings about a very significant alteration to the very legal essence of the Member States' nationalities. Crucially, the humiliation of the state and undermining of the key features of citizenship is not accompanied by a solid doctrinal or practical alternative: we are not shown a new way. Instead, we are constantly treated to the dogmatic mantra of the perceived benefits of the "apolitical" internal market. As a result, morally and ethically vacant reasons rooted in the internal market - such as the programmed-in belief that those who chose to move about in space are entitled to more constitutional protections and are more "valuable" as EU citizens - can set aside fundamental human rights concerns and key principles of the national constitutional law of the Member States. Setting aside the norms of a particular legal order is not a problem per se, of course. It becomes a problem, however, when the reasons underpinning this are not sufficiently clear - if not arcane - and are entirely removed from the realm of democratic testing.

\section{We Have Time: the New Picture Is Here to Stay}

The legal context of the EU, amplifying and reinforcing the global trends in citizenship, equality and democracy, also brings with it grave challenges, and as a path-dependent process faces virtually no serious challenge. Critical analyses of it are equally limited and surprisingly new. ${ }^{104}$ Hungary and Poland, with their crises of the Rule of Law, ${ }^{105}$ or the waving goodbye UK, with its antiimmigration populism, ${ }^{106}$ oppose the EU for entirely different reasons. However, the ongoing process of reinvention both of citizenship and the state in the EU has only just begun. Exposing it with clarity and scrutinising its implications

104 See, e.g., Editorial comments (2015). The Critical Turn in EU Legal Studies. Common Market Law Review $5^{2}$ (4), pp. 881-888 (and the literature cited therein). Cf. Williams, A. (2009). The Ethos of Europe: Values, Law and Justice in the EU. Cambridge: Cambridge University Press; de Witte, F. (2015). Justice in the EU: The Emergence of Transnational Solidarity. Oxford: Oxford University Press.

105 Pech, L., and Scheppele, K.L. (2017). Illiberalism Within: Rule of Law Backsliding in the EU. Cambridge Yearbook of European Legal Studies 19, pp. 3-47; Sadurski, W. (2018). How Democracy Died (In Poland): A Case Study on Anti-Constitutional Populist Backsliding. Sydney Law School Research Paper 1; Szente, Z. (2017). Challenging the Basic Values Problems with the Rule of Law in Hungary and the Failure to Tackle Them. In Jakab, and Kochenov, eds., The Enforcement of EU Law and Values: Ensuring Member States' Compliance. Oxford: Oxford University Press, p. 456.

106 Cf. Closa, C., ed. (2017). Secession from a Member State and Withdrawal from the European Union: Troubled Membership. Cambridge: Cambridge University Press. 
for the development of the constitutional systems around the world is a starting point for coping with a reality which is here to stay. The sterile and cartoonish official story retold in EU textbooks simply does not hold, and States which fail to take note are in danger of getting a rude awakening in the near future, be it through absurd populist victories or by finding themselves attempting to implement Brexit-like claims. An alternative narrative of EU citizenship, to contribute to a sound dynamic understanding of the evolution of statehood and citizenship in Europe and beyond is sorely needed at the moment. EU citizenship, focused on fundamental rights, equality and a critical rethinking of the core grounds behind the division of competences between the EU and the Member States, could provide such a much-needed narrative and a starting point, offering a sounder and less awkwardly "depoliticised" paradigm of European integration than the pure internal market. One can coexist with the other, but the realisation that the essential starting points of the internal market and of EU citizenship are incompatible should necessarily be the starting point of such a journey. ${ }^{107}$

In the light of the above, how far, then, is EU citizenship deserving of its name? The question is open what kind of rights Europeans could legitimately see as unquestionably associated with their supranational citizenship - as opposed to with a proxy of the internal market, that is.

107 Cf. Kochenov, D. (2013) The Citizenship Paradigm. Cambridge Yearbook of European Legal Studies 15, pp. 197-225. 